\title{
Physicochemical Characteristics of Fungal Xylanases and their Potential for Biobleaching of Kraft and Non-wood Pulps
}

\author{
Ana C. F. Kmetzki ${ }^{1}$, Caroline Henn ${ }^{2}$, Sandra S. Moraes ${ }^{1}$, Nyéssia F. S. Silva ${ }^{1}$ \\ and Marina K. Kadowaki ${ }^{{ }^{*}}$ \\ ${ }^{1}$ Centro de Ciências Médicas e Farmacêuticas, Universidade Estadual do Oeste do Paraná, \\ Rua Universitária, 2069, CEP 85819-110, Cascavel, Paraná, Brazil. \\ ${ }^{2}$ Divisão de Reservatório - MARR.CD, Itaipu Binacional, Avenida Tancredo Neves, 6731, \\ CEP 85866-900, Foz do lguaçu, Paraná, Brazil.
}

\begin{abstract}
Authors' contributions
This work was carried out in collaboration among all authors. Authors ACFK and CH designed the study and wrote the first draft of the manuscript. Authors SSM and NFSS managed the literature searches. Author MKK managed the analyses of the study. All authors read and approved the final manuscript.

Article Information

DOI: 10.9734/ARRB/2019/v34i430160 Editor(s): (1) Dr. Bechan Sharma, Department of Biochemistry, University of Allahabad, Allahabad, India.
Reviewers:

(1) Punam Yadav, B. P. Koirala Institute of Health Sciences (BPKIHS), Nepal. (2) Kohji Ishihara, Okayama University of Science, Japan. Complete Peer review History: http://www.sdiarticle4.com/review-history/54733
\end{abstract}

Mini-review Article

Received 07 December 2019

Accepted 14 February 2020

Published 21 February 2020

\section{ABSTRACT}

Xylanases are enzymes with a wide variety of biotechnological applications, such as in the bioconversion of lignocellulosic materials, improvement of feed digestibility, and bleaching kraft pulps to increase pulp brightness. Many studies have been conducted and published over the years on cellulose pulp bleaching due to the need to search for more sustainable tools and thus reduce environmental pollution. Thus, in this review, we focus on analyzing the biochemical properties of xylanases produced by mesophilic and thermophilic fungi that have been used in the bleaching processes of kraft and non-wood pulps. Eucalyptus kraft pulp is still one of the most used raw materials in the production of pulp and paper, while straw and bagasse are alternative sources of non-wood pulps. Thermophilic fungal xylanases show optimum enzymatic activity at high temperatures and a shorter treatment period when compared to mesophilic xylanases in the 
bleaching step. However, mesophilic fungal xylanases exhibit a longer period of enzymatic treatment but achieve a satisfactory brightness and kappa number. Hence, these approaches will contribute to future applications of these xylanolytic enzymes in pulp and paper industries.

Keywords: Brightness; cellulose; fungus; kraft; xylanase.

\section{INTRODUCTION}

The pulp and paper industry is one of the most productive sectors in the world, stimulated by growing global demand. In Brazil, 7.84 million hectares of trees were planted in $2016,34 \%$ of which belong to companies in the pulp and paper industry [1]. The industry is still growing - global paper production hit 400 million tons per year in 2014 - but it is traditionally known to contribute to environmental pollution, mainly due to its discharge of effluent [2]. The most significant environmental impact of the pulp and paper industry is caused by wastewater elimination [3] since it requires 75,000 to 227,000 liters of water per ton of paper produced.

Environmental regulation has increasingly restricted the use of chlorine compounds for the bleaching of kraft pulp since the effluents produced by the industry contain a variety of organic and inorganic contaminants that mostly originate from tannins, lignin, resins, and chlorine compounds [4,5]. Chlorinated organic compounds generated during the bleaching of pulp have been identified as toxic, mutagenic, and bioaccumulative. In addition, these chlorine compounds, even at low concentrations, may cause serious biological disorders $[6,7]$. The pulp and paper industries have adapted to restrictions by using sustainability strategies that minimise their environmental impact. Elemental chlorinefree (ECF) bleaching methods and enzymatic treatments have gained popularity because of environmental concerns about the chlorinated compounds that are generated during the manufacture of cellulose.

In this context, numerous studies have been conducted by many researchers over the years to implement the use of enzymes as xylanases in kraft pulp pre-bleaching processes in order to use increasingly sustainable technologies. Thus, we focus on searching and analysing published data on the physicochemical characteristics of xylanases produced by various species of mesophilic and thermophilic fungi that have been tested in the bleaching processes of kraft and non-wood pulps in order to assist in the future application of these xylanolytic enzymes in pulp bleaching processes.

\section{USE OF FUNGAL XYLANASE IN KRAFT PULP BLEACHING}

In accordance with their commitment to expanding its range of chlorine-free products, the paper industry has adopted enzymes as new, versatile tools. Viikari et al. [8] were the first to describe the use of enzymatic treatment to replace chlorine bleaching for the removal of lignin from wood pulp. Since the kraft bleaching process generates approximately 2 to $4 \mathrm{~kg}$ of organochlorine per tonne of pulp [9], the use of enzymes is a way to reduce the amount of chlorine dioxide required for pulp bleaching. Among the enzymes used, the xylanases are the most popular in the paper industry, where they are utilised as bleach boosting agents [10], reducing the chlorinated chemical volume by up to $25 \%$. Consequently, a proportional reduction in the generation of chlorinated effluent has occurred [10]. Furthermore, when kraft and nonwood pulps were implemented with xylanase in the pre-bleaching stage, the use of chlorinebased chemicals in the subsequent stage was reduced by 20 to $25 \%$, and consequently the levels of pollutants eliminated were reduced [11].

The addition of xylanase during the bleaching step was one of the first reports on the efficient use of enzymes as a technological tool that could be added to an existing industrial plant without large investment. The xylanolytic system includes enzymes such as endo-1,4- $\beta$-xylanases (EC 3.2.1.8), $\beta$-xylosidases (EC 3.2.1.37), $\alpha$-Larabinofuranosidases (EC 3.2.1.55), $\alpha$-Dglucuronidases (EC 3.2.1.139), acetyl xylan esterases (EC 3.1.1.72) and feruloyl esterases (EC 3.1.1.73) [12,4]. Endo-1,4- $\beta$-xylanases (E.C.3.2.1.8) are the main glycosyl hydrolases (GH) of the xylanolytic system and are commonly called "xylanases". The enzymes hydrolyse $\beta-1,4$ glycosidic bonds inside the xylan chain, producing xylooligosaccharides (XOS), and belong to the $\mathrm{GH} 10$ and $\mathrm{GH} 11$ families [13]. Xylan-1,4- $\beta$-xylosidases (E.C.3.2.1.37) act cooperatively with endo-1,4- $\beta$-xylanases, 
Table 1. Physicochemical properties of fungal xylanases and their performance in pulp bleaching

\begin{tabular}{|c|c|c|c|c|c|c|c|c|c|}
\hline Fungus & $\begin{array}{l}\text { Xylanase } \\
\text { (U/g pulp) }\end{array}$ & $\mathrm{pH}$ & $\begin{array}{l}\text { Temperature } \\
\left({ }^{\circ} \mathrm{C}\right)\end{array}$ & $\begin{array}{l}\text { Treatment } \\
\text { period }(\mathrm{h})\end{array}$ & $\begin{array}{l}\text { Kappa } \\
\text { number }\end{array}$ & $\begin{array}{l}\text { Kappa efficiency } \\
(\%)\end{array}$ & $\begin{array}{l}\text { Brightness } \\
(\%)\end{array}$ & Type of pulp & References \\
\hline Aspergillus flavus & 10 & 6.5 & 60 & 1 & 9.02 & 35.93 & $\mathrm{nr}$ & Eucalyptus Kraft pulp & [15] \\
\hline Aspergillus flavus & 11 & 6.5 & 55 & 2 & 89 & 36.32 & $\mathrm{nr}$ & Eucalyptus Cellulose pulp & [16] \\
\hline Aspergillus flavus & 10 & 6.5 & 55 & 2 & 2.56 & 18.34 & $\mathrm{nr}$ & Eucalyptus Cellulose pulp & [17] \\
\hline Aspergillus fumigatus & 10 & $5.0-5.5$ & 70 & 1 & 6.8 & 11.7 & $\mathrm{nr}$ & Eucalyptus Cellulose pulp & [18] \\
\hline Aspergillus japonicus & 10 & 5,2 & 50 & 3 & 11.6 & 25.2 & 57.7 & Eucalyptus Cellulose pulp & [19] \\
\hline Aspergillus niger & 10 & 6.5 & 55 & 2 & 10.34 & 25.93 & $\mathrm{nr}$ & Eucalyptus Cellulose pulp & [16] \\
\hline Aspergillus niger & 35 & 5.5 & 55 & 2 & 7.4 & 14.9 & 59.6 & Eucalyptus Cellulose pulp & [20] \\
\hline Aspergillus niger & 5 & 7 & 50 & 4 & 4.8 & $\mathrm{nr}$ & 70.8 & Cellulose pulp & [21] \\
\hline Aspergillus niger & 60 & $\mathrm{nr}$ & 50 & 2 & 19.9 & $\mathrm{nr}$ & 41.8 & Paper pulp & [22] \\
\hline Aspergillus niveus & 10 & $4.5-5.0$ & 65 & 1 & 7.1 & 39.6 & 58.1 & Eucalyptus Cellulose Kraft & [23] \\
\hline Aspergillus niveus & 35 & 5.5 & 55 & 2 & 6.9 & 20.7 & 59.6 & Cellulose pulp & [20] \\
\hline Aspergillus ochraceus & 35 & 5.5 & 55 & 2 & 6.9 & 20.7 & 58.9 & Cellulose pulp & [20] \\
\hline Aspergillus ochraceus & 10 & 5 & 65 & 1 & 7.5 & 36.4 & 57.1 & Cellulose pulp & [24] \\
\hline Aspergillus oryzae NRRL 1808 & 51 & 6.0 & 60 & $\mathrm{nr}$ & $\mathrm{nr}$ & $\mathrm{nr}$ & 1.4 & Eucalyptus pulp & [25] \\
\hline Aspergillus sydowii SBS 45 & 25 & 8.2 & 40 & 5 & 14.32 & $\mathrm{nr}$ & 41 & Kraft pulp & [26] \\
\hline Aspergillus terricola & 10 & 6.5 & 60 & 1 & 6.6 & 14.3 & 60.3 & Eucalyptus Cellulose pulp & [24] \\
\hline Penicillium corylophilum & 5 & 7 & 50 & 4 & 4.9 & $\mathrm{nr}$ & 73 & Eucalyptus Cellulose Kraft & [21] \\
\hline Penicillium crustosum & 25 & 5.5 & 50 & 2 & 9.77 & $\mathrm{nr}$ & $\mathrm{nr}$ & Eucalyptus Cellulose Kraft & [27] \\
\hline Penicillium janczewskii & 2 & 5.5 & 50 & 1 & $<3$ & $\mathrm{nr}$ & $\mathrm{nr}$ & Eucalyptus Kraft pulp & [28] \\
\hline Penicillium sp & 20 & $\mathrm{nr}$ & 30 & 1 & 2.3 & $\mathrm{nr}$ & 0.9 & Waste office paper & [29] \\
\hline $\begin{array}{l}\text { Thermomyces lanuginosus CBS } \\
288.54\end{array}$ & 40 & $7.0-7.5$ & $70-75$ & 1 & $\mathrm{nr}$ & $\mathrm{nr}$ & 66.91 & Wheat straw pulp & {$[30]$} \\
\hline $\begin{array}{l}\text { Thermomyces lanuginosus wild } \\
\text { type }\end{array}$ & 10 & 7 & 60 & 1.5 & $\mathrm{nr}$ & 8.6 & 2.63 & Wheat straw pulp & [31] \\
\hline $\begin{array}{l}\text { Thermomyces lanuginosus } \\
\text { mutant (M7) }\end{array}$ & 10 & 8 & 65 & 1.5 & 2.29 & 18.6 & $\mathrm{nr}$ & Wheat straw pulp & [31] \\
\hline $\begin{array}{l}\text { Thermomyces lanuginosus } \\
\text { SSBP }\end{array}$ & 50 & 6.5 & 50 & 3 & 9 & $\mathrm{nr}$ & 46.1 & Bagasse pulp & [32] \\
\hline Trichoderma asperellum & 100 & 5.0 & 50 & 1 & 4.2 & $\mathrm{nr}$ & 4 & Paper pulp & [33] \\
\hline Trichoderma longibrachiatum & 5 & 7 & 50 & 4 & 4.3 & $\mathrm{nr}$ & 71.6 & $\begin{array}{l}\text { Cellulose kraft pulp from } \\
\text { Eucalyptus }\end{array}$ & [21] \\
\hline Trichoderma viride & 10 & 6 & & & & $\mathrm{nr}$ & $\mathrm{nr}$ & Kraft pulp from Eucalyptus & [34] \\
\hline
\end{tabular}


converting the xylooligosaccharides from the non-reducing end until D-xylose units and filamentous fungal $\beta$-xylosidases have been described only for families 3,43 and $54[14,13]$. However, many microorganisms, including filamentous fungi, yeast, and bacteria, are recognised producers of these xylanases [12].

Thus, the physicochemical properties of fungal xylanases, as well as results obtained on the bleaching of pulps from studies carried out by several researchers are compiled in a table including treatment conditions for the biobleaching of cellulose pulp and Eucalyptus kraft pulp, treatment period, kappa number and brightness (Table 1).

\section{DISCUSSION}

The bleaching of cellulose pulp, Eucalyptus kraft, or non-wood pulp has been supplemented with xylanases from both mesophilic and thermophilic fungi. Eucalyptus pulp is one of the most commonly used pulps in paper production, while wheat straw represents a common source of alternative raw material or non-wood pulp. Xylanases produced by thermophilic fungi such as Aspergillus fumigatus and Thermomyces lanuginosus show optimum enzymatic activity at high temperatures $\left(70-75^{\circ} \mathrm{C}\right)$, but the treatment period with xylanase is shorter $(0.5 \mathrm{~h})$, an important factor in reducing cost in the bleaching process. In contrast, mesophilic fungal xylanases show optimum activity in the range of $50-55^{\circ} \mathrm{C}$ and acidic $\mathrm{pH}(5.0-6.5)$, require a longer enzyme treatment period $(2-4 \mathrm{~h}$ ) to achieve a satisfactory brightness and have a lower kappa number. According to the properties of the enzyme, a neutral or alkaline $\mathrm{pH}$ also improves pulp bleaching, with a $70.8 \%$ increase in brightness at pH 7.0 [21]. Similarly, xylanases with an optimum $\mathrm{pH}$ of 7.0 from the fungi Penicillium corylophilum and Trichoderma longibrachiatum produced an increase in brightness of $73 \%$ and $71.6 \%$, respectively [21].

Other hemicellulases, such as ferulic acid esterases and galactosidases, have also been reported to help in the bleaching of cellulose pulp with xylanases [4]. While lipases are generally applied during the processing of the paper, xylanase and laccase are more commonly used in the bleaching and delignification processes [35]. The benefits of enzymatic treatment include a reduction of operating costs and organic pollutants, improvement in the brightness and properties of the pulp, reduction of the kappa number, and increase in fiber yield [36]. In addition, bio-bleaching of non-wood kraft pulps (rice straw, wheat straw, bagasse, etc.) treated with $T$. lanuginosus SSBP xylanase released chromophores and organic halogens, reduced sugars, and decreased the kappa number [37].

Several hypotheses have been proposed to explain the role of cellulase-free xylanase in the bleaching of paper pulp: the treatment of cellulose pulp with cellulase-xylanase helps and improves the infiltration of bleaching chemicals, breaking down the xylan structure, and consequently removes the lignin-based chromophores from the cellulose fiber $[8,38,39$, 40]. Some studies have shown that prebleaching with xylanase is an innovative and environmentally friendly, as well as inexpensive, method that can decrease the amount of chemicals needed to achieve a given brightness in the later stages of chemical treatment. Therefore, pre-treatment with xylanases increases the efficiency of the chemical extraction of lignin from pulp and further minimises the need for chlorine dioxide $\left(\mathrm{ClO}_{2}\right)$ $[41,42]$. Thus, a significant number of pulp and paper industries in Europe, North America, South America, and Japan have used enzymes in the kraft bleaching processes. North America has already improved the processing of 2.5 million tonnes of pulp using xylanase in the prebleaching steps [43].

\section{CONCLUSION}

Eucalyptus kraft pulp is still the most reported among pulp and paper production, while wheat straw represents a source of alternative raw material or non-wood pulp. The bleaching of Eucalyptus kraft or non-wood pulps by both mesophilic and thermophilic fungal xylanases has been studied. Thermophilic fungal xylanases have shown optimum enzymatic activity at high temperatures, an advantage because they require a shorter treatment period, which reduces operational cost. On the other hand, mesophilic fungal xylanases are effective in achieving satisfactory results in brightness and a lower kappa number, but they require a longer treatment time compared to thermophilic fungal xylanase. Thus, these approaches will contribute to future applications of these xylanolytic enzymes in pulp and paper industries.

\section{COMPETING INTERESTS}

Authors have declared that no competing interests exist. 


\section{REFERENCES}

1. Brazilian Tree Industry - Report 2017. Indústria Brasileira de Árvores (IBÁ); 2017. Available:http://iba.org/images/shared/Bibli oteca/IBA_RelatorioAnual2017.pdf 2017 Portuguese.

2. Skals PB, Krabek A, Nielsen PH, Wenzel $H$. Environmental assessment of enzyme assisted processing in pulp and paper industry. Int J LCA. 2008;13:124-132. Available:http://dx.doi.org/10.1065/lca2007 .11 .366

3. Pokhrel D, Viraraghavan T. Treatment of pulp and paper mill wastewater- A review. Sci Total Environ. 2004;333:37-58.

Available:https://doi.org/10.1016/j.scitotenv .2004.05.017

4. Polizeli ML, Rizzatti AC, Monti R, Terenzi HF, Jorge JA, Amorim DS. Xylanases from fungi: Properties and industrial applications. J Appl Microbiol Biochem. 2005;67: 577-91.

DOI: $10.1007 / \mathrm{s} 00253-005-1904-7$

5. Ashrafi O, Yerushalmi L, Haghighat $F$. Wastewater treatment in the pulp-andpaper industry: A review of treatment processes and the associated greenhouse gas emission. J Environ Manage. 2015; 158:146-157.

DOI: 10.1016/j.jenvman.2015.05.010

6. Onysko KA. Biological bleaching of chemical pulps: A review. Biotechnol Adv. 1993;11:179-198.

Available:https://doi.org/10.1016/07349750(93)90040-T

7. Dedhia BS, Vetal MD, Rathod VK, Levente C. Xylanase and laccase aided bio-bleaching of wheat straw pulp. Can J Chem Eng. 2014;92:131-138.

Available:https://doi.org/10.1002/cjce.2179 8

8. Viikari L, Ranua $M$, Kantelinen $A$, Sundquist J, Linko M. Bleaching with enzymes. In: 3rd International Conference on biotechnology in the pulp and paper industry in Stockholm; 1986.

9. Kansal SK, Singh M, Sud D. Effluent quality at Kraft/soda agro-based paper mills and its treatment using a heterogeneous photocatalytic system. Desalination. 2008;228:183-190.

Available:https://doi.org/10.1016/j.desal.20 07.10.007

10. Bajpai P, Anand A, Bajpai PK. Bleaching with lignin-oxidizing enzymes. Biotechnol Annu Rev. 2006;12:349-378.
DOI: 10.1016/S1387-2656(06)12010-4

11. Thakur VV, Jain RK, Mathur RM. Studies on xylanase and laccase enzymatic prebleaching to reduce chlorine-based chemicals during $\mathrm{CEH}$ and ECF bleaching. Bioresources. 2012;7:2220-2235.

DOI: 10.15376/biores.7.2.2220-2235

12. Beg QK, Kapoor M, Mahajan L, Hoondal GS. Microbial xylanases and their industrial applications: A review. Appl Microbiol Biotechnol. 2001;56:326-338. DOI: $10.1007 / \mathrm{s} 002530100704$

13. Heinen PR, Betini JHA, Polizeli MLTM. Xylanases, in: Reference Module in Life Sciences, Elsevier. 2017;1-12.

14. Knob A, Terrasan CRF, Carmona EC. $\beta-$ Xylosidases from filamentous fungi: an overview. World J Microbiol Biotechnol. 2010;26:389-407.

Available:http://dx.doi.org/10.1007/s11274009-0190-4

15. Martins MD, Guimarães MW, Lima VA, Gaglioti AL, Da-Silva PR, Kadowaki MK, Knob A. Valorization of passion fruit peel by-product: Xylanase production and its potential as bleaching agent for kraft pulp Biocatal Agric Biotechnol. 2018;172-180.

16. de Alencar Guimaraes $N$, Sorgatto $M$, Peixoto-Nogueira SD, Betini JH, Zanoelo F, Marques M, Polizeli M LTM, Giannesi GC. Bioprocess and biotecnology: Effect of xylanase from Aspergillus niger and Aspergillus flavus on pulp biobleaching and enzyme production using agroindustrial residues as substract. Springer plus. 2013;2:1.

DOI: 10.1186/2193-1801-2-380

17. da Silva PO, Guimarães NCA, PeixotoNogueira SC, Betini JH, Marchetti CR, Zanoelo FF, Polizeli MLTM, Marques MR, Giannesi GC. Production of cellulase-free xylanase by Aspergillus flavus: Effect of polyols on the thermostability and its application on cellulose pulp biobleaching. Afr J Biotechnol. 2015;14:3368-3373.

DOI: 10.5897/AJB2015.14943

18. Peixoto-Nogueira SD, Michelin M, Betini JHA, Jorge JA, Terenzi HF, Polizeli MLTM. Production of xylanase by Aspergilli using alternative carbon sources: Application of the crude extract on cellulose pulp biobleaching. J Ind Microbiol Biotechnol. 2009;36:149- 149-155.

Available:Phttps://doi.org/10.1007/s10295008-0482-y

19. Guimarães NCA, Sorgatto M, PeixotoNogueira SC, Betini JHA, Zanoelo FF, 
Marques M, Polizeli MLTM, Giannesi GC. Xylanase Production from Aspergillus japonicus var aculeatus: Production using Agroindustrial Residues and Biobleaching Effect on Pulp. J Biocatal Biotransformation. 2013; $2: 1$. DOI:10.4172/2324-9099.1000105

20. Betini JHA, Michelin M, Peixoto-Nogueira SC, Jorge JA, Terenzi HF, Polizeli MLTM. Xylanases from Aspergillus niger, Aspergillus niveus and Aspergillus ochraceus produced under solid-state fermentation and their application in cellulose pulp bleaching. Bioprocess Biosyst Eng. 2009;32:819-824.

DOI: $10.1007 / \mathrm{s} 00449-009-0308-y$

21. Medeiros RG, Da Silva JrFG, Báo SN, Hanada R, Ferreira Filho EX. Application of xylanases from amazon forest fungal species in bleaching of eucalyptus kraft pulps. Braz Arch Biol Technol. 2007;50: 231-238.

Available:http://dx.doi.org/10.1590/s151689132007000200008

22. Sridevi A, Sandhya A, Ramanjaneyulu G, Narasimha G, Devi PS. Biocatalytic activity of Aspergillus niger xylanase in paper pulp biobleaching. 3 Biotech. 2016;6(2):165. DOI: 10.1007/s13205-016-0480-0

23. Peixoto-Nogueira SD, Michelin M, Betini JHA, Jorge JA, Terenzi HF, Polizeli MLTM, Production of xylanase by Aspergilli using alternative carbon sources: application of the crude extract on cellulose pulp biobleaching. J Ind Microbiol Biot. 2009; 36:149-155.

24. Michelin $M$, Peixoto-Nogueira SC, Betini JHA, da Silva TM, Jorge JA, Terenzi H, Polizeli MLTM. Production and properties of xylanases from Aspergillus terricola Marchal and Aspergillus ochraceus and their use in cellulose pulp bleaching. Bioproc Biosyst Eng. 2009;33(7):813-821.

25. Szendefy J, Szakacs G, Christopher L. Potential of solid-state fermentation enzymes of Aspergillus oryzae in biobleaching of paper pulp. Enzyme Microb Tech. 2006;39(6):1354-1360.

26. Nair SG, Sindhu R, Shashidhar S. Enzymatic bleaching of kraft pulp by xylanase from Aspergillus sydowii SBS 45. Indian J. Microbiol. 2010;50(3):332-328.

27. Silva NFS, Simões MR, Knob A, Moraes SS, Henn C, Silva JLC, Simão RCG, Maller A, Kadowaki MK. Improvement in the bleaching of Kraft pulp with xylanase from Penicillium crustosum FP 11 isolated from the Atlantic forest. Biocatal Biotransformation. 2016;34:119-127.

DOI: $10.1080 / 10242422.2016 .1212849$

28. Terrasan CRF, Temer B, Sarto C, Silva Junior FG, Carmona EC. Xylanase and $\beta$ xylosidase from Penicillium janczewskii: Production, physico-chemical properties, and application of the crude extract to pulp biobleaching. Bioresources. 2013;8:12921305.

DOI: 10.15376/biores.8.1.1292-1305

29. Sridevi A, Narasimha G, Devi PS. Production of xylanase by Penicillium sp. And its biobleaching efficiency in paper and pulp industry. Int. J Pharm Sci Rev Res. 2019;10(3):1307-1311.

30. Li X, Jiang Z, Li L, Yang SQ, Feng WY, Fan JY, Kusakabe I. Characterization of a cellulase-free, neutral xylanase from CBS 288.54 and its biobleaching effect on wheat straw pulp. Bioresour. Technol. 2005;96:1370-1379.

DOI:10.1016/j.biortech.2004.11.006

31. Bokhari SAI, Rajoka MI, Javaid A, Shafiqur-Rehman, Ishtiaq-ur-Rehman, Latif $F$. Novel thermodynamics of xylanase formation by a 2-deoxy-d-glucose resistant mutant of Thermomyces lanuginosus and its xylanase potential for biobleachability. Bioresour. Technol. 2010;101:2800-2808. Available:https://doi.org/10.1016/j.biortech. 2009.10.072

32. Manimaran A, Kumar KS, Permaul K, Singh S. Hyper production of cellulase-free xylanase by Thermomyces lanuginosus SSBP on bagasse pulp and its application in biobleaching. Appl Microbiol Biotechnol. 2008;81:887-893.

DOI: $10.1007 / \mathrm{s} 00253-008-1693-x$

33. Sridevi A, Ramanjaneyulu G, Suvarnalatha, Devi PS. Biobleaching of paper pulp with xylanase produced by Trichoderma asperellum. 3 Biotech. 2017;7(4):266.

DOI: $10.1007 / \mathrm{s} 13205-017-0898-z$

34. Fortkamp D, Knob A. High xylanase production by Trichoderma viride using pineapple peel as substrate and its application in pulp biobleaching. Afr. J. Biotechnol. 2014;13:2248-2259.

DOI: $10.5897 / A J B 2013.13479$

35. Demuner BJ, Junior NP, Antunes AMS. Technology prospecting on enzymes for the pulp and paper industry. JOTMI. 2011; 6:148-158.

Available:http://dx.doi.org/10.4067/s071827242011000300011 
36. Gangwar AK, Prakash NT, Prakash R. Applicability of microbial xylanases in paper pulp bleaching: A review. Bioresources. 2014;9:3733-3754.

DOI: 10.15376/biores.9.2.3733-3754

37. Ziaie-Shirkolaee $\mathrm{Y}$, Talebizadeh A, Soltanali S. Comparative study on application of $T$. lanuginosus SSBP xylanase and commercial xylanase on biobleaching of non-wood pulps. Bioresour Technol. 2008;99:7433-7437.

DOI: 10.1016/j.biortech.2008.02.032.

38. Viikari L, Kantelinen A, Sundquist J, Linko M. Xylanases in bleaching: From an idea to the industry. FEMS Microbiol Rev. 1994; 13:335-350.

Available:https://doi.org/10.1111/j.15746976.1994.tb00053.x

39. Walia A, Mehta P, Guleria S, Shirkot CK. Modification in the properties of paper by using cellulase-free xylanase produced from alkalophilic Cellulosimicrobium cellulans CKMX1 in biobleaching of wheat straw pulp. Can J Microbiol. 2015;61:671681.

DOI: $10.1139 /$ cjm-2015-0178.

40. Kumar A, Gautam A, Dutt D, Yadav M, Sehrawat N, Kumar P. Applications of microbial technology in the pulp and paper industry. In book - Microbiology and Biotechnology. Publisher: Nova Science Publishers, New York, USA, Editors: Vikas Kumar, Gulab Singh, Neeraj K. Aggarwal. 2017;185-206.

41. Khonzue $\mathrm{P}$, Laothanachareon $\mathrm{T}$, Rattanaphan N, Tinnasulanon P, Apawasin $\mathrm{S}$, Paemanee $\mathrm{A}$, et al. Optimization of xylanase production from Aspergillus niger for biobleaching of eucalyptus pulp. Biosci Biotechnol Biochem. 2011;75:11291134.

Available:https://doi.org/10.1271/bbb.1100 32

42. Walia A, Guleria S, Mehta P, Chauhan A, Parkash J. Microbial xylanases and their industrial application in pulp and paper biobleaching: a review. 3 Biotech. 2017;7: 11.

DOI: 10.1007/s13205-016-0584-6.

43. Nguyen $D$, Zhang $X$, Jiang $Z H$, Audet $A$, Paice MG, Renaud S, Tsang A. Bleaching of Kraft pulp by a commercial lipase: Accessory enzymes degrade hexenuronic acids. Enzyme Microb Tech. 2008;43: 130-136.

DOI: 10.1016/j.enzmictec.2007.11.012

(c) 2019 Kmetzki et al.; This is an Open Access article distributed under the terms of the Creative Commons Attribution License (http://creativecommons.org/licenses/by/4.0), which permits unrestricted use, distribution, and reproduction in any medium, provided the original work is properly cited.

Peer-review history:

The peer review history for this paper can be accessed here: http://www.sdiarticle4.com/review-history/54733 